\title{
Total Synthesis of Ritterazine B
}

\author{
Yasuaki Nakayama $\$$, Michael R. Maser $\$$, Tatsuya Okita, Anton V. Dubrovskiy, Taryn L. Campbell, and \\ Sarah E. Reisman*
}

The Warren and Katharine Schlinger Laboratory for Chemistry and Chemical Engineering, Division of Chemistry and Chemical Engineering, California Institute of Technology, Pasadena, California 91125, United States

\section{Supporting Information Placeholder}

ABSTRACT: The first total synthesis of the cytotoxic alkaloid ritterazine $B$ is reported. The synthesis features a unified approach to both steroid subunits, employing a titanium-mediated propargylation reaction to achieve divergence from a common precursor. Other key steps include gold-catalyzed cycloisomerizations that install both spiroketals, and late stage $\mathrm{C}-\mathrm{H}$ oxidation to incorporate the $\mathrm{C7}^{\prime}$ alcohol.

Ritterazine B (1) is a bis-steroidal pyrazine (BSP) natural product that was isolated in 1995 from the marine tunicate Riterella tokioka off of Japan's Izu Peninsula. ${ }^{1}$ The BSPs include some of the most potent anticancer compounds discovered to date, ${ }^{2}$ and $\mathbf{1}$ in particular has been described as "among the most potent growth inhibitors ever tested" by the National Cancer Institute $(\mathrm{NCl}) .^{3-5}$ It possesses sub-nanomolar activity against P388 leukemia cells $\left(0.17 \mathrm{nM} \mathrm{GI}_{50}\right)^{6}$ and an average $\mathrm{GI}_{50}$ of $3.2 \mathrm{nM}$ in the $\mathrm{NCl}-60$ cell line screen. ${ }^{5,7}$ Given that the BSPs display distinct activity patterns in $\mathrm{NCl}-60$ COMPARE analyses, they are proposed to act by a distinct mode of action from existing chemotherapies. ${ }^{4,7,8}$

Although the BSPs are known to induce apoptosis, ${ }^{3}$ a lack of natural material has hampered translational investigations of $\mathbf{1}$ and related compounds. Landmark studies from Shair and co-workers implicated BSPs as high-affinity ligands for oxysterol binding proteins, ${ }^{4}$ while more recent evidence has suggested that the endoplasmic reticulum-specific heat-shock protein GRP78 may be their efficacious target. ${ }^{9,10}$ Given these promising foundational studies, improved synthetic access to 1 is required to fully evaluate its potential as a chemotherapeutic. ${ }^{2,8}$ In this communication, we report the first total synthesis of $\mathbf{1}$. Our approach uses a common strategy to prepare both of the steroid spiroketals from trans-dehydroandrosterone, a commercially available and inexpensive steroid.

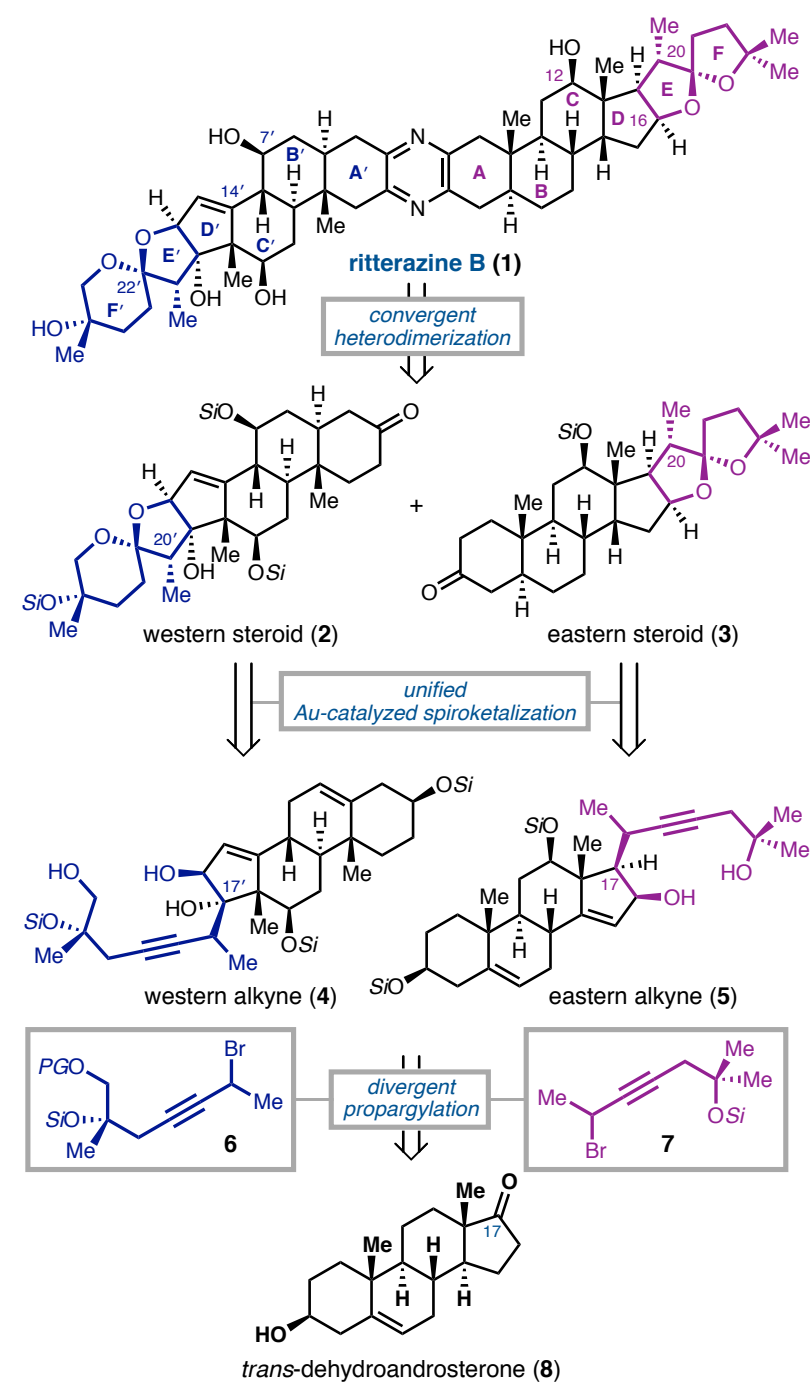

Figure 1. Retrosynthetic analysis.

In line with prior efforts to the BSPs, ${ }^{5,11}$ our retrosynthetic analysis began with scission of the central pyrazine ring, revealing the 'western' and 'eastern' steroids $\mathbf{2}$ and $\mathbf{3}$, respectively (Figure 1 ). To streamline our route development, we sought to prepare both $\mathbf{2}$ and $\mathbf{3}$ 
from a common starting material, using the same general tactics for $\mathrm{C}-\mathrm{C}$ bond formation and spiroketalization. In this vein, steroids $\mathbf{2}$ and $\mathbf{3}$ were simplified to the corresponding alkynes $\mathbf{4}$ and $\mathbf{5}$, where transition metalcatalyzed cycloisomerization ${ }^{12}$ would be used to form the respective spiroketals. This retrosynthetic step shifted the synthetic challenge to the union of differentiated alkyne fragments with a common steroid core. We envisioned preparing alkynes 4 and 5 by 1,2-addition of the propargyl-metal species derived from 6 or 7 to an $\alpha$ hydroxy ketone accessible from transdehydroandrosterone (8). The choice of $\mathbf{8}$ as the starting material was seen as strategic: the $\mathrm{C} 5-\mathrm{C} 6$ alkene would provide a handle for late-stage B-ring oxidation. This tactic has yet to be utilized in synthetic approaches to the BSPs, ${ }^{11}$ which could be why BSPs with $\mathrm{C} 7 / \mathrm{C7}^{\prime}$ oxidation have not previously been synthesized. ${ }^{7}$

In the forward sense, known steroid 9 (prepared in two steps from $\mathbf{8})^{13}$ was treated with excess tertbutyldimethylsilyl triflate and triethylamine $\left(\mathrm{Et}_{3} \mathrm{~N}\right)$ to protect the $\mathrm{C} 3$ and $\mathrm{C} 12$ alcohols and form of a silyl enol ether at C17 (Scheme 1A). Direct addition of isopropanol and $\mathrm{N}$-bromosuccinimide to the reaction mixture afforded $\alpha$-bromo-ketone $\mathbf{1 0}$ in quantitative yield in one pot. Elimination of the $\mathrm{C} 16$ bromide under basic conditions gave an inconsequential mixture of isomeric enones ( $\Delta^{14-15}$ and $\Delta^{15-16}$, not shown), which converged to dienol ether 11 on treatment with $\mathrm{Et}_{3} \mathrm{~N}$ and trimethylsilyl triflate. Selective epoxidation of the C16-C17 alkene with dimethyldioxirane and subsequent addition of tetrabutylammonium fluoride (TBAF) provided $\alpha$ hydroxy-ketone 12 in $92 \%$ yield, which would serve as our divergent intermediate.

At this stage, we turned our attention to preparing the distinct spiroketals found in the western and eastern steroids $\mathbf{2}$ and $\mathbf{3}$, respectively. To this end, titaniummediated propargylations based on conditions reported by Sato and co-workers proved uniquely effective (Scheme 1B). ${ }^{14}$ Deprotonation of the $\mathrm{C} 16$ alcohol by treatment of 12 with $n$-butyllithium, followed by addition of the organotitanium species derived from either propargyl bromide 6 or 7 resulted in 1,2-addition to give alkyne 13 in $54 \%$ yield or 14 in $56 \%$ yield. These additions occurred with exclusive $\beta$-face selectivity despite the axial methyl group, ${ }^{15}$ possibly due to the formation of an $\alpha$-disposed cyclic chelate between the C16 and C17 oxygens. While excellent diastereoselectivity was obtained at $\mathrm{C} 17, \mathbf{1 3}$ and $\mathbf{1 4}$ were formed as 1:1 mixtures of epimers at $\mathrm{C} 20^{\prime} / \mathrm{C} 20$ (vide infra).

While the $\alpha$-stereoisomer of the C16 alcohol was crucial for imparting the desired stereocontrol in the propargylation reactions, we required the $\beta$-oriented alcohols to elaborate to the required spiroketals. For the preparation of the western steroid (2), stereoinversion was accomplished by oxidation to the enone followed by cleavage of the $p$-methoxyphenyl ether ${ }^{16}$ and hydroxyl-directed 1,2-reduction, which furnished spiroketal precursor 4 in $86 \%$ yield (Scheme 2A). After extensive experimentation, ${ }^{17}$ treatment of diol 4 with catalytic ${ }^{C}$ JohnPhos.AuCl (10 mol \%) and $\mathrm{AgBF}_{4}(5 \mathrm{~mol} \%)$ provided spiroketal 15 in $68 \%$ yield as a single diastereomer. ${ }^{12}$ To our delight, this reaction not only provided the correct configuration at the spiroketal, but also proceeded with convergence of the $\mathrm{C}^{2} \mathrm{O}^{\prime}$ epimers, furnishing $\mathbf{1 5}$ with the required $\alpha$-disposed methyl group. The overall selectivity was found to be critically dependent on the choice of dichloroethane solvent, ${ }^{c}$ JJohnPhos ligand, and tetrafluoroborate counterion.

With the western spirocycle in hand, allylic oxidation of 15 at $\mathrm{C7}^{\prime}$ was achieved with oxochromate $(\mathrm{Cr}(\mathrm{V})) .{ }^{18}$ To obtain the fully saturated $\mathrm{B}^{\prime}$ ring, the intermediate enone (not shown) was reduced with $\mathrm{Sml}_{2}$ and 2-naphtalene thiol to furnish $\mathbf{1 6}$ in $85 \%$ yield as a single diastereomer; low temperatures were crucial for preventing over-reduction of the $\mathrm{C} 14-\mathrm{C} 15$ alkene. ${ }^{17}$ Protection of the $\mathrm{C7}^{\prime}$ alcohol of $\mathbf{1 6}$ as the tri-isopropylsilyl ether was followed by addition of $\mathrm{Et}_{3} \mathrm{~N} \cdot 3 \mathrm{HF}$ to selectively reveal the $\mathrm{C}^{\prime}$ alcohol in the same pot.

\section{Scheme 1. Preparation of the western and eastern alkyne fragments}
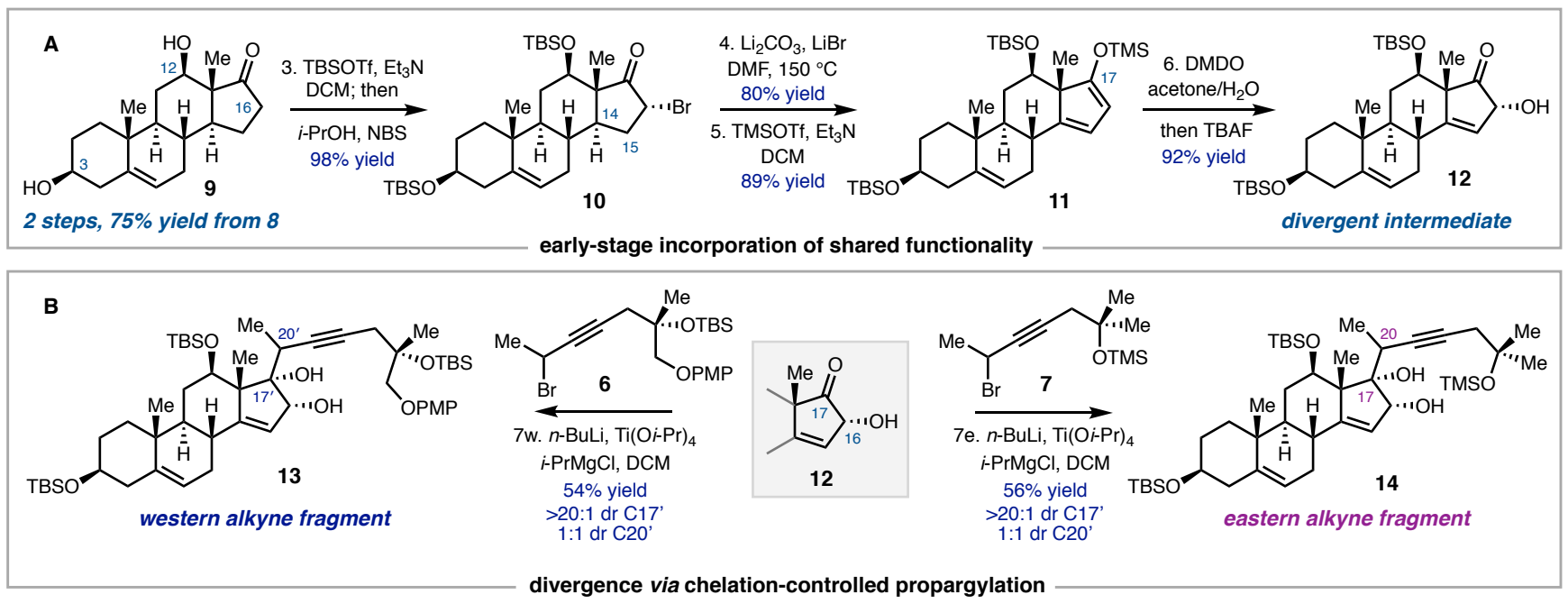


\section{Scheme 2. Total synthesis of ritterazine B}
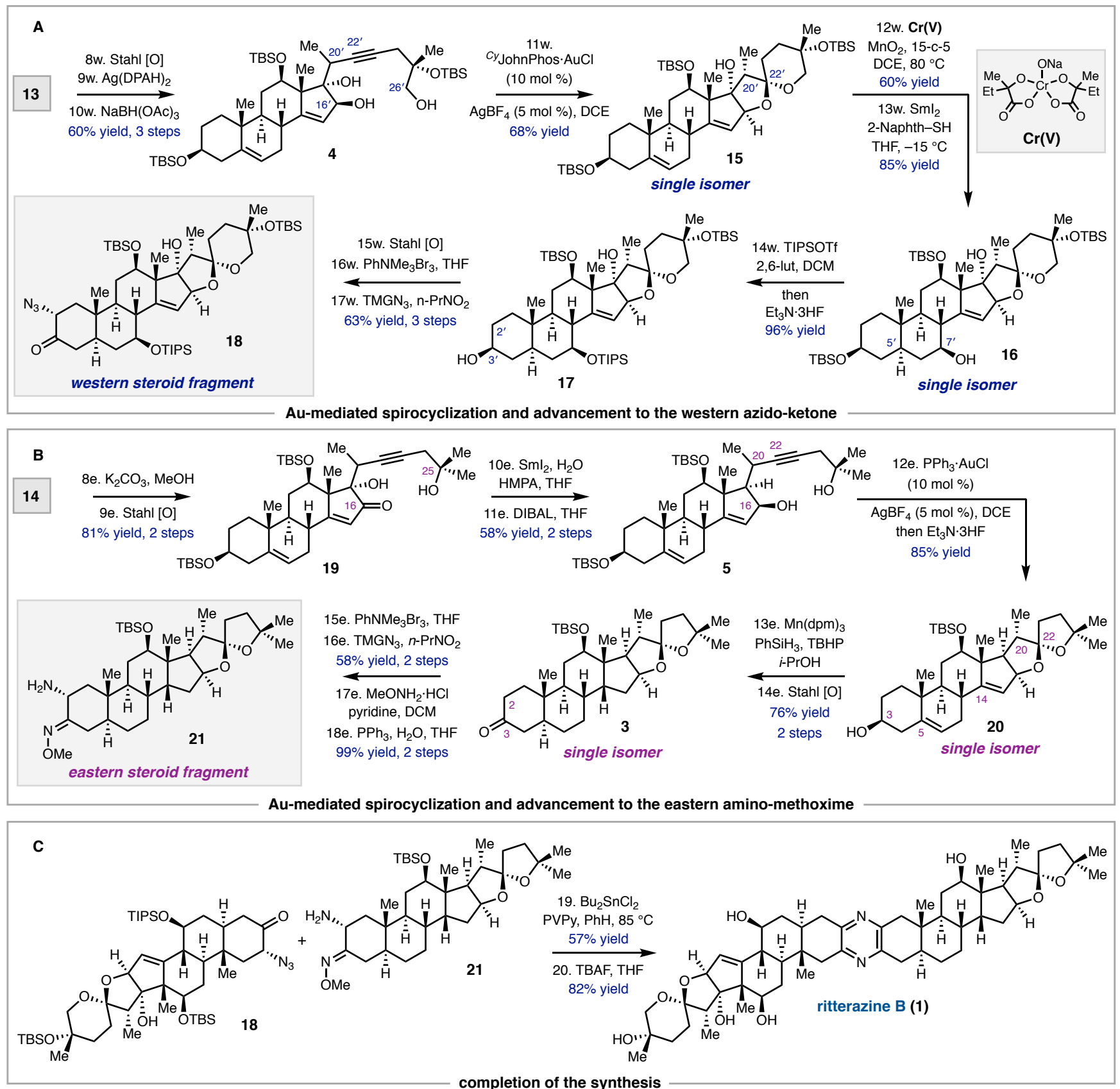

Oxidation of 17 to the ketone and two-step $\alpha$ bromination and azidation at $\mathrm{C} 2$ using procedures developed by Shair ${ }^{11 \mathrm{i}}$ and Fuchs ${ }^{11 \mathrm{~d}}$ provided the western fragment as keto-azide 18 in $63 \%$ overall yield. The use of nitropropane as solvent for the azidation instead of the traditional nitromethane was found necessary for solubilization of the intermediate bromide. ${ }^{11 d, i}$ This also significantly increased the yield by preventing undesired elimination of $\mathrm{N}_{2}$ from 18.

The synthesis of the eastern steroid followed a similar sequence to that described above, but was modified slightly to prepare diol 5 (Scheme 2B). Following deprotection of the trimethylsilyl ether in $\mathbf{1 4}$ and Stahl oxidation, the $\mathrm{C} 17$ alcohol was removed via ketol deoxygenation with $\mathrm{Sml}_{2}$ and $\mathrm{H}_{2} \mathrm{O} .{ }^{19}$ 


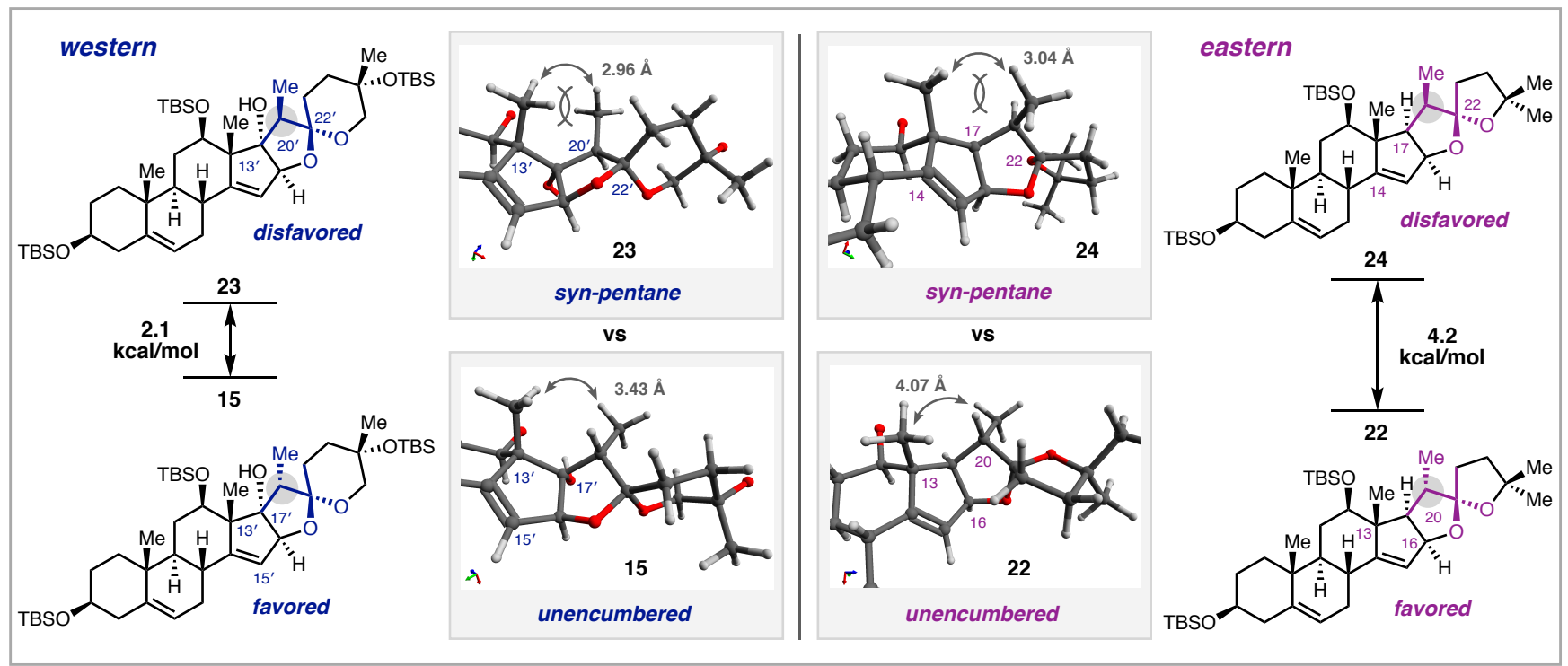

Figure 2. Thermodynamic evaluation of $\mathrm{C} 2 \mathrm{O} / \mathrm{C} 2 \mathrm{O}^{\prime}$ epimers of the spiroketalization products.

Diastereoselective 1,2-reduction was effected by treatment with di-iso-butylaluminum hydride to give $\mathbf{5}$; the four electron reduction of $\mathbf{1 9}$ directly to give $\mathbf{5}$ could be accomplished with excess $\mathrm{Sml}_{2}$, though the yield and diastereoselectivity was greatly reduced relative to the two-step procedure.

As observed for the western fragment, $A u(I)-$ catalyzed spirocyclization proceeded smoothly to construct the $5 / 5(E / F)$ ring system, again as a single isomer at both $\mathrm{C} 20$ and $\mathrm{C} 22$. Here, it was found that direct addition of $\mathrm{Et}_{3} \mathrm{~N} \cdot 3 \mathrm{HF}$ to the reaction mixture resulted in selective deprotection of the C3 silyl ether, ultimately providing $\mathbf{2 0}$ in $\mathbf{8 5 \%}$ yield.

The remaining two stereocenters required for the eastern fragment were installed in a single step via hydrogen atom transfer (HAT) reduction of the $\mathrm{C} 5-\mathrm{C} 6$ and C14-C15 alkenes under conditions developed by Shenvi and co-workers. ${ }^{20}$ The fully saturated product was obtained with cis-fusion at the C/D ring-junction; DFT studies supported the thermodynamic preference for the observed stereochemistry. ${ }^{17,20}$ This reaction proved critical for accessing late-stage material in the correct oxidation state, as typical alkene hydrogenation conditions were unable to reduce the $\mathrm{C} 14-\mathrm{C} 15$ double bond. To complete the eastern coupling partner, the same oxidation/bromination/azidation protocol as described for the western fragment was followed by ketone condensation with $\mathrm{MeONH}_{2} \cdot \mathrm{HCl}$ and Staudinger reduction ${ }^{21}$ to furnish amino-methoxime $\mathbf{2 1}$ in quantitative yield. ${ }^{11 \mathrm{~d}}$

Heterodimerization under Lewis-acid catalysis, as originally reported by Fuchs, ${ }^{11 d}$ provided the desired pyrazine (Scheme 2C). Global deprotection with TBAF $F^{11 i}$ delivered ritterazine $B$ in $82 \%$ yield, representing its first total synthesis. Spectroscopic characterization data matched that reported for the natural material. ${ }^{1}$

The construction of each fragment hinged on the modular spiroketalization reaction. Given the observed epimerization at $\mathrm{C} 2 \mathrm{O} / \mathrm{C} 2 \mathrm{O}^{\prime}$, we hypothesize that the process occurs through an initial stereoablative monocyclization/isomerization, followed by a doublydiastereoselective ketal formation.5,12a To probe the preferential formation of the $\mathrm{C} 2 \mathrm{O} / \mathrm{C} 2 \mathrm{O}^{\prime}$ stereocenters, ground-state energies were calculated for DFToptimized 15 and 22 (Figure 2). Indeed, the observed isomers were found to be 2.1 and $4.2 \mathrm{kcal} / \mathrm{mol}$ lower in energy than their un-natural $\mathrm{C} 20$ and $\mathrm{C} 2 \mathrm{O}^{\prime}$ epimers, respectively. ${ }^{22}$ Conformational analysis of the disfavored species $\mathbf{2 3}$ and $\mathbf{2 4}$ revealed the existence of synpentane-like interactions between the $\mathrm{C} 20 / \mathrm{C}^{\prime} \mathrm{O}^{\prime}-\beta-\mathrm{Me}$ and the axial C13/C13'-Me groups. ${ }^{5,23}$ These interactions are not present with the $\alpha$-disposed C20-Me groups, which appear less sterically encumbered.

In summary, the first total synthesis of ritterazine B has been completed starting from the simple steroid trans-dehydroandrosterone and using a unified approach to both steroid fragments. Key features of the strategy include titanium-mediated propargylations to access differentiated alkynes as well as gold-catalyzed, diastereoselective spirocyclizations to forge the spiroketals. The modularity of this approach has allowed access to three additional BSPs to date, including two novel non-natural compounds. Investigations into the biological activity of $\mathbf{1}$ and related compounds are currently underway, which will be reported in due course. It is worth noting that several multi-milligram batches of these materials have been prepared thus far, and though we have elected to perform the final steps on small scale for safety, synthesis of the coupling frag- 
ments has proven to be scalable. We expect that our developed route will provide ample material for biological studies, enabling further investigation of the BSPs as anticancer therapeutics.

\section{ASSOCIATED CONTENT}

The Supporting Information is available free of charge on the ACS Publications website.

Experimental procedures, characterization data $\left({ }^{1} \mathrm{H}\right.$ and ${ }^{13} \mathrm{C}$ NMR, HRMS, FTIR) for all new compounds (pdf).

\section{AUTHOR INFORMATION}

\section{Corresponding Author}

Sarah E. Reisman - The Warren and Katharine Schlinger Laboratory for Chemistry and Chemical Engineering, Division of Chemistry and Chemical Engineering, California Institute of Technology, Pasadena, California 91125, United States; orcid: 00000001-8244-9300; E-mail: reisman@caltech.edu

\section{Author Contributions}

\$These authors contributed equally.

\section{ACKNOWLEDGMENT}

Dr. Scott Virgil and the Caltech Center for Catalysis and Chemical Synthesis are gratefully acknowledged for access to analytical equipment. We thank Arthur Han for early studies. Fellowship support was provided by the NSF (M. R. M., Grant No. DGE1144469), the Japan Society for the Promotion of Science (Y. N.), and Ishihara Sangyo Kaisha (T. O.). S.E.R. is a Heritage Medical Research Institute Investigator, and acknowledges financial support from the American Cancer Society.

\section{REFERENCES}

(1) Fukuzawa, S.; Matsunaga, S.; Fusetani, N. Isolation and Structure Elucidation of Ritterazines B and C, Highly Cytotoxic Dimeric Steroidal Alkaloids, from the Tunicate Ritterella Tokioka. J. Org. Chem. 1995, $60(3), 608-614$.

(2) Moser, B. R. Review of Cytotoxic Cephalostatins and Ritterazines: Isolation and Synthesis. J. Nat. Prod. 2008, 71 (3), 487-491.

(3) Komiya, T.; Fusetani, N.; Matsunaga, S.; Kubo, A.; Kaye, F. J.; Kelley, M. J.; Tamura, K.; Yoshida, M.; Fukuoka, M.; Nakagawa, K. Ritterazine B, a New Cytotoxic Natural Compound, Induces Apoptosis in Cancer Cells. Cancer Chemother. Pharmacol. 2003, 51 (3), 202-208.

(4) Burgett, A. W. G.; Poulsen, T. B.; Wangkanont, K.; Anderson, D. R.; Kikuchi, C.; Shimada, K.; Okubo, S.; Fortner, K. C.; Mimaki, Y.; Kuroda, M.; Murphy, J. P.; Schwalb, D. J.; Petrella, E. C.; Cornella-Taracido, I.; Schirle, M.; Tallarico, J. A.; Shair, M. D. Natural Products Reveal Cancer Cell Dependence on Oxysterol-Binding Proteins. Nat. Chem. Biol. 2011, 7 (9), 639-647.

(5) Phillips, S. T.; Shair, M. D. Syntheses of the Eastern Halves of Ritterazines $B, F, G$, and $H$, Leading to Reassignment of the 5,5Spiroketal Stereochemistry of Ritterazines B and F. J. Am. Chem. Soc. 2007, 129 (20), 6589-6598.

(6) Fukuzawa, S.; Matsunaga, S.; Fusetani, N. Isolation of $13 \mathrm{New}$ Ritterazines from the Tunicate Ritterella Tokioka and Chemical Transformation of Ritterazine B1. J. Org. Chem. 1997, 62 (13), 4484-4491.
(7) Budzikiewicz, H.; Flessner, T.; Jautelat, R.; Scholz, U.; Winterfeldt, E. Progress in the Chemistry of Organic Natural Products; Springer Vienna: Vienna, 2004.

(8) Imperatore, C.; Aiello, A.; D’Aniello, F.; Senese, M.; Menna, M. Alkaloids from Marine Invertebrates as Important Leads for Anticancer Drugs Discovery and Development. Molecules 2014, 19 (12), 20391-20423.

(9) López-Antón, N.; Rudy, A.; Barth, N.; Schmitz, L. M.; Pettit, G. R.; Schulze-Osthoff, K.; Dirsch, V. M.; Vollmar, A. M. The Marine Product Cephalostatin 1 Activates an Endoplasmic Reticulum Stress-Specific and Apoptosome-Independent Apoptotic Signaling Pathway. J. Biol. Chem. 2006, 281 (44), 33078-33086.

(10) Ambrose, A. J.; Santos, E. A.; Jimenez, P. C.; Rocha, D. D.; Wilke, D. V.; Beuzer, P.; Axelrod, J.; Kumar Kanduluru, A.; Fuchs, P. L.; Cang, H.; Costa-Lotufo, L. V.; Chapman, E.; La Clair, J. J. Ritterostatin GN1N, a Cephalostatin-Ritterazine Bis-Steroidal Pyrazine Hybrid, Selectively Targets GRP78. ChemBioChem 2017, 18 (6), 506-510.

(11) (a) Jeong, J. U.; Fuchs, P. L. Synthesis of a 17-Deoxy, C-14,15Dihydro Derivative of the North Spiroketal Moiety of the Cephalostatins. Conversion to a (+)-Trisdecacyclic C2 Symmetrical Pyrazine. J. Am. Chem. Soc. 1994, 116 (2), 773-774. (b) Heathcock, C. H.; Smith, S. C. Synthesis and Biological Activity of Unsymmetrical BisSteroidal Pyrazines Related to the Cytotoxic Marine Natural Product Cephalostatin 1. J. Org. Chem. 1994, 59 (22), 6828-6839. (c) Jeong, J. U.; Sutton, S. C.; Kim, S.; Fuchs, P. L. Biomimetic Total Syntheses of (+)-Cephalostatin 7, (+)-Cephalostatin 12, and (+)-Ritterazine K. J. Am. Chem. Soc. 1995, 117 (40), 10157-10158. (d) Guo, C.; Bhandaru, S.; Fuchs, P. L.; Boyd, M. R. An Efficient Protocol for the Synthesis of Unsymmetrical Pyrazines. Total Synthesis of Dihydrocephalostatin 11. J. Am. Chem. Soc. 1996, 118 (43), 10672-10673. (e) LaCour, T. G.; Guo, C.; Bhandaru, S.; Boyd, M. R.; Fuchs, P. L. Interphylal Product Splicing: The First Total Syntheses of Cephalostatin 1, the North Hemisphere of Ritterazine G, and the Highly Active Hybrid Analogue, Ritterostatin GN1N1. J. Am. Chem. Soc. 1998, 120 (4), 692-707. (f) Jeong, J. U.; Guo, C.; Fuchs, P. L. Synthesis of the South Unit of Cephalostatin. 7. Total Syntheses of (+)-Cephalostatin 7, (+)-Cephalostatin 12, and (+)-Ritterazine K1. J. Am. Chem. Soc. 1999, 121 (10), 20712084. (g) Kim, S.; Sutton, S. C.; Guo, C.; LaCour, T. G.; Fuchs, P. L. Synthesis of the North 1 Unit of the Cephalostatin Family from Hecogenin Acetate1. J. Am. Chem. Soc. 1999, 121 (10), 2056-2070. (h) Lee, S.; Fuchs, P. L. The First Total Synthesis of (Corrected) Ritterazine M. Org. Lett. 2002, 4 (3), 317-318. (i) Fortner, K. C.; Kato, D.; Tanaka, Y.; Shair, M. D. Enantioselective Synthesis of (+)Cephalostatin 1. J. Am. Chem. Soc. 2010, 132 (1), 275-280.

(12) (a) Liu, B.; De Brabander, J. K. Metal-Catalyzed Regioselective Oxy-Functionalization of Internal Alkynes: An Entry into Ketones, Acetals, and Spiroketals. Organic Letters 2006, 8 (21), 4907-4910. (b) Tlais, S. F.; Dudley, G. B. A Gold-Catalyzed Alkyne-Diol Cycloisomerization for the Synthesis of Oxygenated 5,5-Spiroketals. Beilstein J. Org. Chem. 2011, 7, 570-577. (c) Goodwin, J. A.; Aponick, A. Regioselectivity in the Au-Catalyzed Hydration and Hydroalkoxylation of Alkynes. Chem. Commun. 2015, 51 (42), 8730-8741. (d) Pflästerer, D.; Rudolph, M.; Hashmi, A. S. K. Gold-Catalyzed Hydrofunctionalizations and Spiroketalizations of Alkynes as Key Steps in Total Synthesis. Isr. J. Chem. 2018, 58 (5), 622-638.

(13) (a) Schönecker, B.; Lange, C.; Zheldakova, T.; Günther, W.; Görls, H.; Vaughan, G. Copper-Mediated Regio- and Stereoselective $12 \beta$ Hydroxylation of Steroids with Molecular Oxygen and an Unexpected 12 $\beta$-Chlorination. Tetrahedron 2005, 61 (1), 103-114. (b) Trammell, R.; See, Y. Y.; Herrmann, A. T.; Xie, N.; Díaz, D. E.; Siegler, Maxime. A.; 
Baran, P. S.; Garcia-Bosch, I. Decoding the Mechanism of Intramolecular $\mathrm{Cu}$-Directed Hydroxylation of $\mathrm{sp}^{3} \mathrm{C}-\mathrm{H}$ Bonds. J. Org. Chem. 2017, 82 (15), 7887-7904.

(14) Nakagawa, T.; Kasatkin, A.; Sato, F. Highly Efficient Synthesis of Propargyl- and Allenyltitanium Reagents from Propargyl Halides or Propargyl Alcohol Derivatives. Practical Synthesis of Allenyl and Homopropargyl Alcohols. Tetrahedron Lett. 1995, 36 (18), 32073210.

(15) (a) Smith, H.; Huges, G. A.; Douglas, G. H.; Wendt, G. R.; Buzby Jr., G. C.; Edgren, R. A.; Fisher, J.; Foell, T.; Gadsby, B.; Hartley, D.; Herbst, D.; Jansen, A. B. A.; Ledig, K.; McLoughlin, B. J.; McMenamin, J.; Pattison, T. W.; Phillips, P. C.; Rees, R.; Siddall, J.; Siuda, J.; Smith, L. L.; Tokolics, J.; Watson, D. H. P. Totally Synthetic Steroid Hormones. Part II. 13b-Alkylgona-1,3,5(10)-Trienes, 13b-Alkygon-4-En-3Ones, and Related Compounds. J. Chem. Soc. 1964, 4472-4492. (b) McKinney, A. R.; Suann, C. J.; Stenhouse, A. M. A Stereochemical Examination of the Equine Metabolism of $17 \alpha$-Methyltestosterone. Anal. Chim. Acta 2007, 581 (2), 377-387.

(16) Noshita, T.; Sugiyama, T.; Kitazumi, Y.; Oritani, T. Phenolic Ferrier Reaction and Its Application to the Natural Product Synthesis. Tetrahedron Lett. 1994, 35 (44), 8259-8262.

(17) See the Supporting Information.

(18) (a) Krumpolc, M.; Rocek, J. Chromium(V) Oxidations of Organic Compounds. Inorg. Chem. 1985, 24 (4), 617-621. (b) Kanda, Y.; Ishi- hara, Y.; Wilde, N. C.; Baran, P. S. Two-Phase Total Synthesis of Taxanes: Tactics and Strategies. J. Org. Chem. 2020, 85 (16), 1029310320.

(19) Szostak, M.; Spain, M.; Procter, D. J. Recent Advances in the Chemoselective Reduction of Functional Groups Mediated by Samarium(li) lodide: A Single Electron Transfer Approach. Chem. Soc. Rev. 2013, 42 (23), 9155-9183.

(20) Iwasaki, K.; Wan, K. K.; Oppedisano, A.; Crossley, S. W. M.; Shenvi, R. A. Simple, Chemoselective Hydrogenation with Thermodynamic Stereocontrol. J. Am. Chem. Soc. 2014, 136 (4), 1300-1303.

(21) Staudinger, H.; Meyer, J. Über neue organische Phosphorverbindungen III. Phosphinmethylenderivate und Phosphinimine. Helv. Chim. Acta 1919, 2 (1), 635-646.

(22) Calculated using the entos software package at the BLYP/631G** theory level. See Manby, F.; Miller, T.; Bygrave, P.; Ding, F.; Dresselhaus, T.; Batista-Romero, F.; Buccheri, A.; Bungey, C.; Lee, S.; Meli, R.; Miyamoto, K.; Steinmann, C.; Tsuchiya, T.; Welborn, M.; Wiles, T.; Williams, Z. Entos: A Quantum Molecular Simulation Package. ChemRxiv 2019, No. 7762646.v2.

(23) Chen, R.; Shen, Y.; Yang, S.; Zhang, Y. Conformational Design Principles in Total Synthesis. Angew. Chem., Int. Ed. 2020, 59 (34), 14198-14210. 


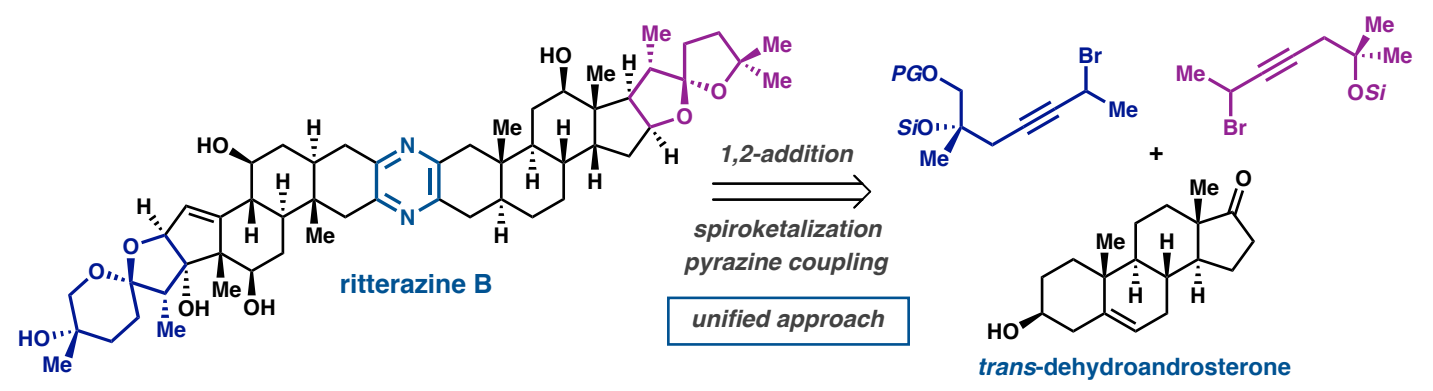

